\title{
Sweet's syndrome: a rare extraintestinal manifestation of ulcerative colitis
}

\author{
Richard Stevenson, ${ }^{1}$ Jonathan Hannay ${ }^{2}$
}

${ }^{1}$ Queen Elizabeth University Hospital, Glasgow, UK ${ }^{2}$ Department of General Surgery, Inverclyde Royal Hospital, Greenock, UK

\section{Correspondence to} Dr Richard Stevenson, richardstevenson1@nhs.net

Accepted 27 April 2016
CrossMark

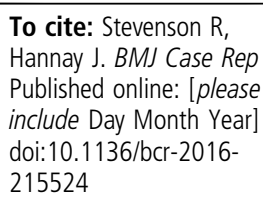

\section{DESCRIPTION}

A 50-year-old man presented with mild proctitis, biopsies of which indicated chronic inflammatory bowel disease. Despite mesalazine suppositories, he progressed to severe colitis affecting the descending colon to the rectum. He proved refractory to steroids and was started on azathioprine and infliximab; however, he failed to improve and underwent a subtotal colectomy with ileostomy 3 months after initial presentation. Pathology showed active, chronic inflammation present from the caecum distally with cryptitis, crypt abscesses and extensive mucosal ulceration down to and in some areas through the muscularis propria. Typical features of Crohn's disease such as granulomas were absent, and the condition was thought more in keeping with ulcerative colitis. The patient was readmitted 2 months later with an exacerbation of his colitis affecting his rectal stump and fever. An elevated neutrophil count and marked extraintestinal manifestations were noted including multiple tender skin papules (figure 1) affecting his trunk, face and extremities, mouth ulcers, arthralgia and uveitis (figure 2). Biopsies of the skin lesions demonstrated primarily an infiltration of mature neutrophils,

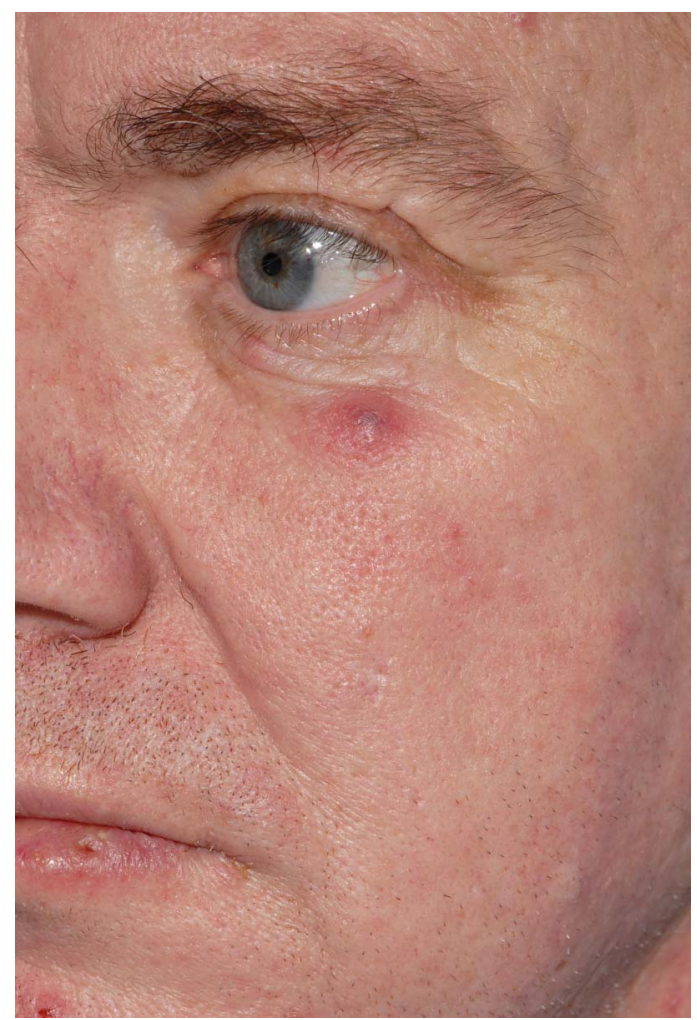

Figure 1 Facial skin papules, biopsy of which demonstrating Sweet's syndrome.

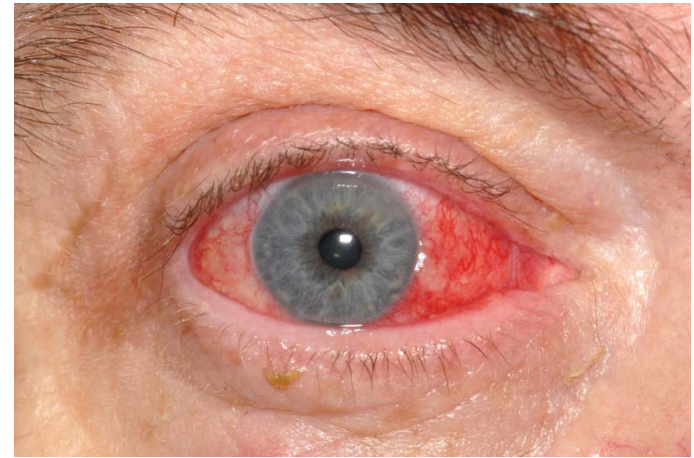

Figure 2 Ocular manifestation indicative of uveitis.

which, in conjunction with his clinical presentation, was indicative of Sweet's syndrome. Human leucocyte antigen (HLA) typing revealed the patient was homozygous for HLA-A, HLA-B and HLA-C, specifically indicating presence of HLA-A*11, HLA-B*35, HLA-C*04, HLA-DRB1*01, HLA-DRB4*01, HLA-DQB1*03. To the authors' knowledge, this HLA type has not previously been associated with Sweet's syndrome. The patient responded well to an intensification of his immunosuppression, with intravenous hydrocortisone, mesalazine and azathioprine, and he was again discharged home with a view to elective completion proctectomy.

\section{Learning points}

Extraintestinal manifestations (EIM) of inflammatory bowel disease (IBD) are common, affecting $25-40 \%$ of patients with IBD. ${ }^{1}$

- The precise aetiology underlying the association between IBD and EIM remains unclear, with many advocating that IBD is a systemic autoimmune disease with the most marked symptoms apparent in the intestine. ${ }^{2}$

- The most commonly affected organs outside of the gastrointestinal tract are musculoskeletal, ocular and dermatological; however, almost every other system can be affected, including the hepatobiliary, genitourinary, vascular, cardiac, pulmonary and endocrine. ${ }^{3}$

Contributors RS and JH were responsible for the diagnosis and management of this patient. RS coordinated the photography and coauthored the case report with $\mathrm{JH}$.

Competing interests None declared.

Patient consent Obtained. 


\section{Images in...}

Provenance and peer review Not commissioned; externally peer reviewed.

\section{REFERENCES}

1 Orchard T. Extraintestinal complications of inflammatory bowel disease. Curr Gastroenterol Rep 2003;5:512-17.
2 Danese $S$, Semeraro S, Papa A. Extraintestinal manifestations in inflammatory bowel disease. World J Gastroenterol 2005;11:7227-36.

3 Baumgart DC, Sandborn WJ. Inflammatory bowel disease: clinical aspects and established and evolving therapies. Lancet 2007;369:1641-57.

Copyright 2016 BMJ Publishing Group. All rights reserved. For permission to reuse any of this content visit http://group.bmj.com/group/rights-licensing/permissions.

BMJ Case Report Fellows may re-use this article for personal use and teaching without any further permission.

Become a Fellow of BMJ Case Reports today and you can:

- Submit as many cases as you like

- Enjoy fast sympathetic peer review and rapid publication of accepted articles

- Access all the published articles

- Re-use any of the published material for personal use and teaching without further permission

For information on Institutional Fellowships contact consortiasales@bmjgroup.com

Visit casereports.bmj.com for more articles like this and to become a Fellow 